\title{
FAKTOR - FAKTOR YANG MEMPENGARUHI STRUKTUR MODAL PADA PERUSAHAAN MANUFAKTUR SEKTOR INDUSTRI DASAR DAN KIMIA YANG TERDAFTAR DI BURSA EFEK INDONESIA PERIODE 2014 - 2016
}

\author{
Budhi Gunawan \\ Program Studi Magister Manajemen Universitas Tarumanagara \\ budhigunawan92@hotmail.com
}

\begin{abstract}
This study analyzes the factors that affected the capital structure of chemicals and basic industry sectors from manufacturing companies which were listed on the Indonesia Stock Exchange during 2014-2016. The study were conducted by examining the effect of firm size, liquidity, profitability, business risk, and asset structure on capital structure. This data were collected from the financial report of 27 manufacture basic industry and chemicals sectors which were listed on Bursa Efek Indonesia in 2014-2016. The multiple regressions analysis and classic assumption test have been performed by sing SPSS 22.0 version statistic test instrument. The result of the research shows that the research regression model has fulfilled the requirements there are no symptoms of multicollinearity, heteroscedasticity, and correlation and the in used file is normally distributed. The result of the research shows: profitability, firm size, liquidity, business risk, asset structure has significant influence to the capital structure.
\end{abstract}

Keywords : Capital Structure, Profitability, Firm Size, Liquidity, Business Risk, Asset Structure.

\section{Latar Belakang Masalah}

Dunia bisnis yang sedang memasuki era globalisasi mengakibatkan persaingan semakin tajam, sehingga setiap perusahaan dituntut untuk senantiasa berproduksi secara efisien bila ingin tetap memiliki keunggulan daya saing. Setiap perusahaan harus mampu bersaing dan mengembangkan usahanya untuk dapat mempertahankan kelangsungan hidup dan mencapai tujuannya. Tujuan perusahaan yaitu untuk mencari keuntungan yang pada akhirnya untuk meningkatkan kesejahteraan bagi para pemilik dan pemegang saham. Untuk dapat meningkatkan kesejahteraan para pemegang saham dapat dilakukan dengan meningkatkan nilai perusahaan, dam cara untuk meningkatkan nilai perusahaan adalah melalui pengelolalaan komposisi modal perusahaan.

Pada prinsipnya perusahaan membutuhkan dana untuk pengembangan bisnisnya. Pemenuhan dana tersebut berasal dari internal dan eksternal. Struktur modal merupakan masalah penting bagi perusahaan. Pentingnya struktur modal adalah karena adanya hubungan antara nilai perusahaan dan biaya modal yang dikeluarkan Sehubungan dengan penyajian laporan keuangan kepada pihak ekstern perusahaan seperti investor dan kreditor, maka setiap perusahaan harus memiliki struktur modal yang baik.

Struktur modal merupakan faktor penting dalam kelangsungan hidup perusahaan. Oleh karena itu, manajemen keuangan perusahaan harus perlu membuat suatu keputusan yang tepat dalam pembentukan struktur modal. Struktur modal optimum menurut Riyanto (2011) adalah struktur modal yang dapat meminimumkan biaya penggunaaan modal rata - rata (average cost of capital). Untuk dapat membentuk struktur modal yang optimal, perusahaan perlu mengetahui seberapa besar dana yang diperlukan oleh perusahaan, selain itu perusahaan juga perlu mengetahui faktor - faktor apa saja yang dapat mempengaruhi struktur modal. Dengan membentuk struktur modal yang optimal, diharapkan perusahaan dapat menarik investor dengan lebih banyak. 


\section{Kerangka Teoritis}

\section{Asymmetric Information Theory}

Teori Asymmetric menurut Brealey dan Myers (2003) dalam Firnanti (2011) mengemukakan bahwa manager perusahaan akan mempunyai informasi yang lebih banyak mengenai prospek dan risiko yang dihadapi perusahaan. Keadaan ini memungkinkan manajer menggunakan informasi yang diketahuinya untuk mengambil keputusan, khususnya pendanaan perusahaan. Dalam Asymmetric Theory dijelaskan juga bahwa ukuran perusahaan berpengaruh terhadap lebih tertutup atau terbukanya perusahaan untuk membagi informasi kepada pihak luar. Perusahaan kecil menganggap membagi informasi kepada pihak pemberi pinjaman membutuhkan biaya yang bsar. Hal ini menghambat penggunaan pendanaan eksternal dan meningkatkan kecendrungan bagi perusahaan kecil untuk menggunakan modal di ekuitas.

\section{Pecking Order Theory}

Menurut Ross, et al (2009) Pecking Order Theory adalah salah satu teori yang mendasarkan pada asimetri informasi. Asimetri informasi akan mempengaruhi struktur modal perusahaan dengan cara membatasi akses pada sumber pendanaan dari luar. Menurut Mayangsari (2001) dalam Firnanti menyatakan bahwa Pecking Order Theory cenderung memilih pendanaan sesuai dengan urutan risiko, yaitu laba ditahan, utang, dan terakhir penerbitan ekuitas. Pecking Order Theory menyatakan bahwa perusahaan dengan tingkat pertumbuhan yang cepat harus lebih banyak mengandalkan pada modal eksternal. Dengan demikian perusahaan dengan tingkat pertumbuhan yang tinggi cenderung lebih banyak menggunakan utang.

\section{Signaling Theory}

Teori Signaling menurut Brigham dan Ehrhardt (2008) mengungkapkan bahwa perusahaan dengan prospek yang bagus tidak menghendaki pendanaan dengan menjual saham baru, sedangkan perusahaan dengan prospek yang tidak bagus memang menyukai pendanaan dengan ekuitas dari luar. Dengan kata lain, pengumuman emisi saham oleh suatu perusahaan umumnya merupakan suatu isyarat bahwa manajemen memandang prospek perusahaan tersebut sedang tidak bagus.

\section{Capital Structure}

Menurut Keown dan Martin (2010) struktur modal adalah campuran sumber dana jangka panjang yang digunakan perusahaan untuk menjalankan perusahaannya. Dalam melakukan investasi, perusahaan berusaha untuk menciptakan nilai, yaitu selisih antara pengembalian atas proyek dengan nilai ekonomis yang dikorbankan untuk proyek tersebut. Oleh karena itu struktur modal menentukan bagaimana nilai diciptakan yang tercermin dar laba dan harga saham perusahaan. (Nanok, 2008 dalam Hardianti dan Gunawan, 2010). Struktur modal dalam penelitian menggunakan rasio total hutang terhadap total aktiva yang dimiliki oleh perusahaan.

\section{Profittability}

Tujuan perusahaan yaitu menghasilkan laba baik dalam jangka pendek maupun jangka panjang. Sartono (2011) mengatakan profitabilitas adalah kemampuan perusahaan memperoleh laba dalam hubungannya dengan penjualan, total aktiva maupun modal sendiri. Menurut Brigham dan Houston (2004) mengatakan bahwa perusahaan dengan tingkat pengembalian yang tinggi atas investasi akan menggunakan hutang yang relatif kecil. Tingkat pengembalian yang tinggi memungkinkan untuk membiayai sebagian besar kebutuhan pendanaan dengan dana yang dihasilkan secara internal.

\section{Firm Size}

Menurut Firnanti (2011) ukuran perusahaan dapat diartikan sebagai ukuran atau besarnya asset yang dimiliki perusahaan. Ukuran perusahaan terbukti memiliki peranan penting dalam menentukan pilihan struktur modal yang akan digunakan oleh suatu perusahaan. Perusahaan 
dengan skala yang besar lebih memiliki sumber pendanaan yang lebih kuat dibandingan dengan perusahaan dengan skala yang kecil.

\section{Liquidity}

Menurut Sartono (2011) likuiditas adalah kemampuan untuk membayar kewajiban financial jangka pendek tepat pada waktunya. Likuiditas perusahaan ditunjukkan oleh besar kecilnya aktiva lancar yaitu aktiva yang mudah untuk diubah menjadi kas yang meliputi kas, surat berharga, piutang, dan persediaan. Rasio likuiditas adalah rasio yang menunjukkan hubungan kas dan aktiva lancar lainnya dengan kewajiban lancar (Brigham dan Houston, 2004).

\section{Business Risk}

Risiko bisnis adalah ketidakpastian yang dihadapi perusahaan dalam menjalankan kegiatan bisnisnya (Hardianti dan Gunawan, 2010). Risiko bisnis perusahaan sangat berpengaruh terhadap kelangsungan hidup perusahaan. Apabila perusahaan tidak dapat menanggung biaya - biaya operasi yang ditimbulkan dalam kegiatan operasinya maka perusahaan tersebut akan dihadapkan pada risiko kebangkrutan. Risiko perusahaan yang tinggi akan lebih mengutamakan pendanaan internal daripada penggunaan hutang maupun penerbitan saham.

\section{Asset Structure}

Struktur aktiva mencerminkan dua komponen aktiva yaitu aktiva lancar dan aktiva tetap. Kebanyakan perusahaan industri dimana sebagian besar daripada modalnya tertanam dalam aktiva tetap, akan mengutamakan pemenuhan modalnya dari modal permanen, yaitu modal sendiri dan hutang sifatnya sebagai pelengkap (Furi dan Saifudin, 2012). Jadi semakin besar jumlah asset suatu perusahaan. Memungkinkan semakin tingginya jumlah pinjaman jangka panjang dan keadaan ini akan meningkatkan struktur modal perusahaan.

\section{Hipotesis}

Hipotesis 1 : profitability berpengaruh terhadap struktur modal

Hipotesis 2 : firm size berpengaruh terhadap struktur modal

Hipotesis 3 : liquidity berpengaruh terhadap struktur modal

Hipotesis 4 : business risk berpengaruh terhadap struktur modal

Hipotesis 5 : asset structure berpengaruh terhadap struktur modal

\section{Metodologi Penelitian}

Populasi yang digunakan dalam penelitian ini adalah seluruh perusahaan yang terdaftar di Bursa Efek Indonesia (BEI) periode 2014 sampai dengan 2016. Sampel pada penelitian ini adalah perusahaan sektor industri dasar dan kimia yang terdaftar di Bursa Efek Indonesia (BEI) periode 2014 sampai dengan 2016. Metode pengambilan sample yang digunakan adalah purposive sampling. Dari perusahaan sektor industri dasar dan kimia yang terdaftar di Bursa Efek Indonesia (BEI) pada periode 2014 - 2016 diambil dua puluh tujuh sampel yang telah memenuhi kriteria yang diinginkan. Data dari dua puluh tujuh perusahaan yang dijadikan sampel diperoleh dari laporan keuangan tahun 2014 sampai dengan tahun 2016. Penelitian ini menggunakan persamaan regresi linier berganda dengan menggunakan metode Statistical Product and Service Solution (SPSS) versi 22.0. 


\section{Operasionalisasi Variabel}

Data dari setiap variabel dalam penelitian ini menggunakan rasio keuangan yang telah dirangkum di tabel 3.1 yaitu:

Tabel 3.1

Operasionalisasi Variabel

\begin{tabular}{|lc|}
\hline Variabel & $\begin{array}{c}\text { Indikator } \\
\text { Capital Structure }\end{array}$ \\
Profitability & $\mathrm{DR}=\frac{\text { Total Debt }}{\text { Total Assets }}$ \\
Firm Size & $\mathrm{NPM}=\frac{\text { EAT }}{\text { Sales }}$ \\
Liquidity & Size $=$ Log (Total Assets $)$ \\
Business Risk & $\mathrm{CR}=\frac{\text { Current Assets }}{\text { Current Liabilities }}$ \\
Asset Structure & $\mathrm{BEPR}=\frac{\text { EBIT }}{\text { Total Assets }}$ \\
& $\mathrm{SA}=\frac{\text { Fixed Assets }}{\text { Total Assets }}$ \\
& \\
\hline
\end{tabular}

Uji Statistik Deskriptif. Uji statistik deskriptif memberikan gambaran atau deskripsi suatu data yang dilihat dari rata - rata (mean), standar deviasi, maximum, minimum, dan sum.

\section{Uji Asumsi Klasik}

Pengujian asumsi klasik bertujuan untuk mengetahui dan menguji kelayakan atas model regresi yang digunakan dalam penelitian ini. Berikut beberapa uji asumsi klasik yang digunakan dalam penelitian ini yaitu:

1. Uji Normalitas. Uji ini bertujuan untuk menguji apakah dalam model regresi variabel independen dan variabel dependen telah terdistribusi secara normal. Penelitian ini menggunakan One-Sample Kolmogorov-Smirnov.

2. Uji Multikolonieritas. Uji ini bertujuan untuk menguji apakah model regresi ditemukan adanya korelasi antar variabel bebas. Untuk menguji ada tidaknya multikolonieritas dilihat dari nilai tolerance atau VIF. Model regresi akan bebas dari multikolonieritas jika nilai tolerance mendekati 1 dan nilai VIF berada di bawah angka 10 (Ghozali, 2011).

3. Uji Autokorelasi. Pengujian ini bertujuan untuk melihat apakah terjadi kesalingtergantungan antar variabel bebas yang digunakan pada penelitian ini. Uji ini menggunakan Durbin Watson test.

4. Uji Heteroskedastisitas. Uji ini bertujuan untuk menguji apakah dalam model regresi terjadi ketidaksamaan variance dari residual satu pengamatan ke pengamatan yang lain. Uji dilakukan dengan menggunakan uji Glejer. Jika korelasi antara variabel independen dengan residual diatas 0,05 maka dapat dikatakan bahwa tidak terjadi heteroskedastisitas pada model regresi.

\section{Uji Hipotesis dan Analisis Data}

Hipotesis dalam penelitian ini diuji menggunakan regresi linear berganda dengan menggunakan program spss versi 22.0. Persamaan regresi linier berganda dalam penelitian ini adalah

Keterangan:

$$
Y=a+b_{1} x_{1}+b 2 \times 2+b 3 \times 3+b 4 \times 4+b 5 \times 5+e
$$

Y

a

$b_{1}, b_{2}, b_{3}, b_{4}, b_{5}$

$\mathrm{X}_{1}$

$$
\begin{aligned}
& =\text { Capital Structure } \\
& =\text { Konstanta } \\
& =\text { Koefisien regresi dari setiap variabel independen } \\
& =\text { Profitability }
\end{aligned}
$$




\begin{tabular}{|c|c|}
\hline $\mathrm{X}_{2}$ & $=$ Firm Size \\
\hline $\mathrm{x}_{3}$ & $=$ Liquidity \\
\hline $\mathrm{X}_{4}$ & $=$ Business Risk \\
\hline $\mathrm{X}_{5}$ & $=$ Asset Structure \\
\hline $\mathrm{e}$ & $=$ Error \\
\hline
\end{tabular}

Uji Korelasi Ganda (Uji R). Uji ini untuk menentukan apakah hubungan variabel independen dengan variabel dependen kuat atau lemah. Nilai R berkisar antara nol dan satu.

Uji Koefisien Determinasi (Adjusted $\mathbf{R}^{2}$ ). Uji ini untuk mengukur seberapa jauh kemampuan model dalam menerangkan variasi variabel terikat. Nilai koefisien determinasi adalah antara nol dan satu.

Uji F (Uji Simultan). Untuk mengetahui apakah variabel - variabel independen secara simultan berpengaruh signifikan terhadap variabel dependen. Dengan nilai signifikan dibawah 0,05 maka semua variabel independen secara bersama - sama mempengaruhi variabel dependen.

Uji t (Uji Parsial). Untuk mengetahui apakah variabel - variabel independen secara parsial berpengaruh atau tidak berpengaruh terhadap variabel dependen. Apabila nilai signifikansi lebih kecil dari 0,05 maka suatu variabel independen secara parsial mempengaruhi variabel dependen (Ghozali, 2011).

\section{Hasil Dan Pembahasan}

\section{Uji Statistik Deskriptif}

Analisis statistik deskriptif sebagai alat untuk menganalisa data dengan cara menggambarkan sampel yang telah ada tanpa maksud membuat kesimpulan yang berlaku umum atau generalisasi. Statistik deskriptif memberikan gambaran atau deskripsi suatu data yang dilihat dari mean, minimum, maximum, dan standar deviasi.

\begin{tabular}{|l|r|r|r|r|r|}
\multicolumn{7}{|c|}{ Tabel 4.1 Statisik Deskriptif } \\
& \multicolumn{1}{|c|}{ N } & Minimum & Maximum & \multicolumn{1}{c|}{ Mean } & Std. Deviation \\
\hline Struktur Modal & 81 &, 07146 &, 83746 &, 3795139 &, 19489824 \\
Ukuran Perusahaan & 81 & 11,12640 & 13,64569 & 12,2156990 &, 66854449 \\
Likuiditas & 81 & 1,00084 & 15,16460 & 3,2894757 & 3,17966018 \\
Proftabilitas & 81 &, 00669 &, 27653 &, 0798728 &, 06700352 \\
Risiko Bisnis & 81 &, 00235 &, 27667 &, 0880687 &, 06305095 \\
Struktur Aktiva & 81 &, 04 &, 80 &, 3802 &, 17694 \\
Valid N (listwise) & 81 & & & & \\
\hline
\end{tabular}




\section{Uji Asumsi Klasik \\ 1. Uji Normalitas}

Tabel 4.2 Uji Normalitas

\begin{tabular}{|ll|r|}
\hline & & Unstandardized Residual \\
\hline Normal Parameters ${ }^{\text {ab }}$ & Mean & 81 \\
& Std. Deviation & $0 \mathrm{E}-7$ \\
& Absolute &, 10936447 \\
& Positive &, 059 \\
Most Extreme Differences & Negative &, 059 \\
& &,- 049 \\
Kolmogorov-Smirnov Z & &, 533 \\
Asymp. Sig. (2-tailed) & &, 939 \\
\hline
\end{tabular}

Berdasarkan tabel diatas didapatkan nilai pengujian menggunakan uji KolmogorovSmirnov sebesar 0,533 dengan Asymp.Sig (2-tailed) sebesar 0,939. Nilai 0,939 lebih besar dari 0,05 maka data tersebut terdistrbusi secara normal.

\section{Uji Multikolinearitas}

Tabel 4.3 Uji Multikolinearitas

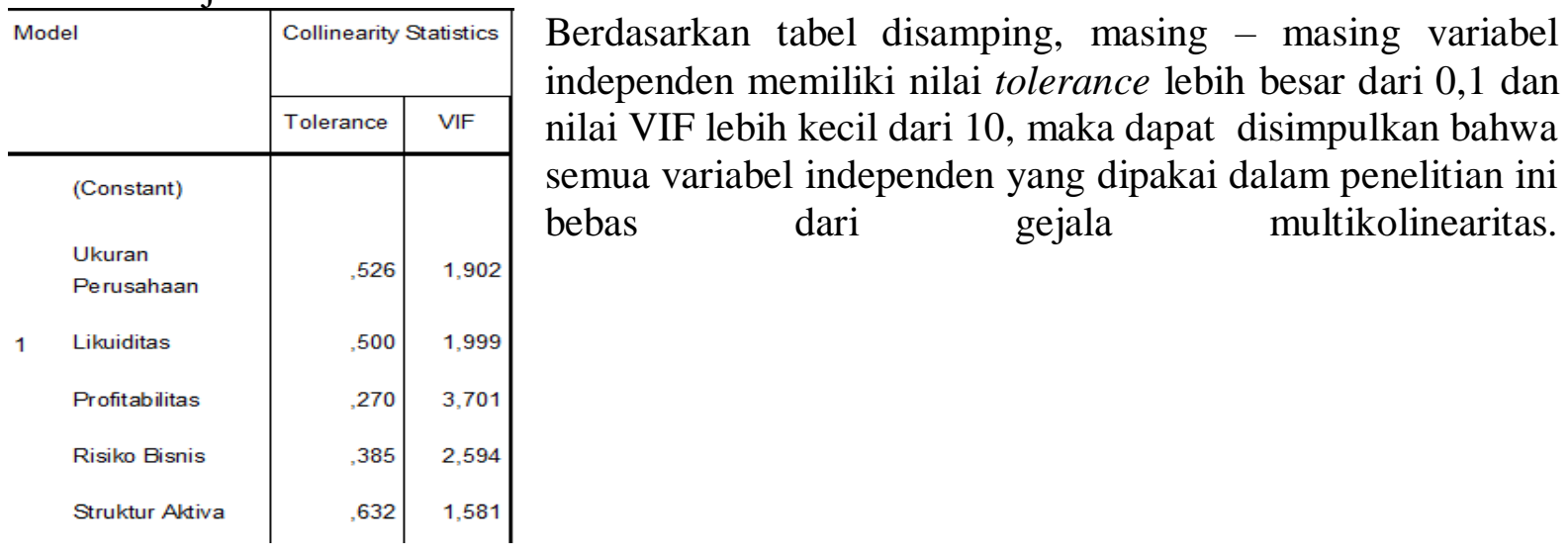

\section{Uji Autokorelasi}

Tabel 4.4 Uji Autokorelasi

\begin{tabular}{|l|r|r|r|r|r|}
\hline Model & \multicolumn{1}{|c|}{$\mathrm{R}$} & \multicolumn{1}{c|}{$\mathrm{R}$ Square } & Adjusted R Square & \multicolumn{1}{|c|}{$\begin{array}{c}\text { Std. Error of the } \\
\text { Estimate }\end{array}$} & \multicolumn{1}{c|}{ Durbin-Watson } \\
\hline 1 &, $828^{a}$ &, 685 &, 664 &, 11295114 & 2,012 \\
\hline
\end{tabular}

Berdasarkan tabel Durbin Watson, maka diperoleh DU untuk $\mathrm{K}=5$ dan $\mathrm{N}=81$ sebesar 1,772 dan nilai DU untuk 4 - DU sebesar $4-1,772=2,228$. Maka dapat disimpulkan :

$$
\mathrm{dU}<\mathrm{DW}<4-\mathrm{dU}=1,772<2,012<2,228
$$

Dapat disimpulkan model regresi tidak terdapat autokorelasi.

\section{Uji Heteroskedastisitas}

Tabel 4.5 Uji Heteroskedastisitas 


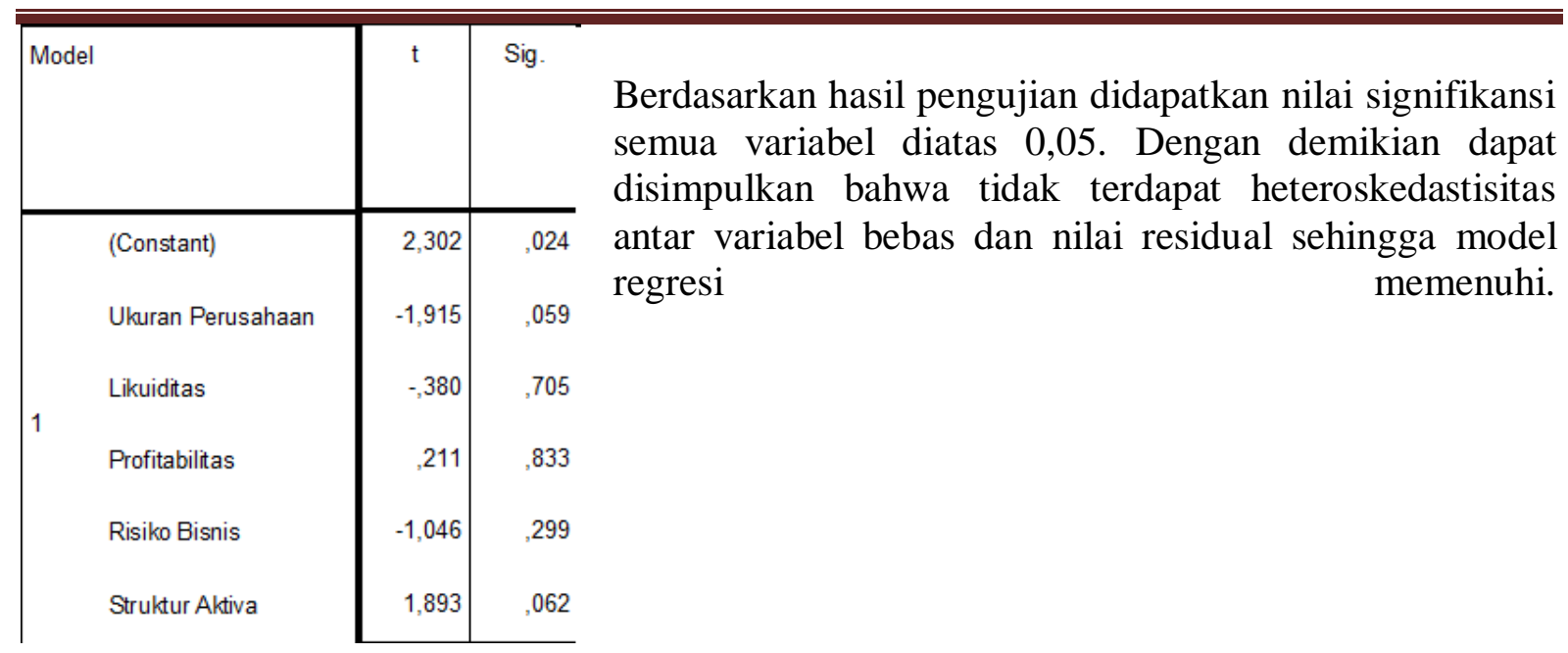

Uji Korelasi Ganda (Uji R) dan Uji Koefisien Determinasi (Adjusted $\mathbf{R}^{2}$ ) Tabel 4.6 Uji R \& Uji Adjusted R ${ }^{2}$

\begin{tabular}{|l|r|r|r|r|r}
\hline Model & R & R Square & Adjusted R Square & $\begin{array}{c}\text { Std. Error of the } \\
\text { Estimate }\end{array}$ & Durbin-Watson \\
\hline 1 &, $828^{\mathrm{a}}$ &, 685 &, 664 &, 11295114 & 2,012 \\
\hline
\end{tabular}

Berdasarkan tabel diatas didapatkan nilai $\mathrm{R}$ sebesar 0,828 dimana angka ini mendekati 1 maka disimpulkan hubungan variabel independen terhadap variabel dependen mendekati kuat. besarnya Adjusted R Square sebesar 0,664 dengan demikian besarnya pengaruh yang diberikan oleh variabel independen terhadap struktur modal sebesar $66 \%$ dan sisanya $34 \%$ dipengaruhi oleh variabel yang tidak diteliti dalam penelitian ini.

\section{Uji F (Uji Simultan)}

Berdasarkan hasil uji $\mathrm{F}$ didapatkan hasil $0,000<0,05$. Sehingga dapat disimpukan variabel independen memiliki pengaruh secara signifikan terhadap variabel dependen.

Tabel 4.7 Uji F

\begin{tabular}{|c|c|c|c|c|c|c|}
\hline \multicolumn{2}{|c|}{ Model } & Sum of Squares & df & Mean Square & $\mathrm{F}$ & Sig. \\
\hline \multirow{3}{*}{1} & Regression & 2,082 & 5 & , 416 & 32,638 &, $000^{\mathrm{b}}$ \\
\hline & Residual & ,957 & 75 &, 013 & & \\
\hline & Total & 3,039 & 80 & & & \\
\hline
\end{tabular}




\section{Uji t (Uji Parsial)}

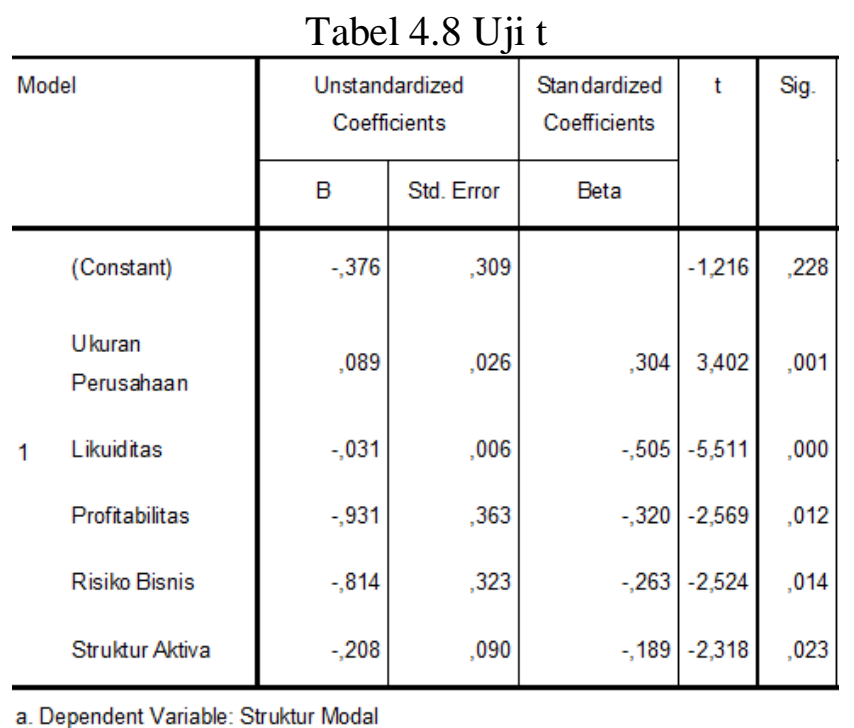

Berdasarkan hasil uji t pada tabel 4.8, variabel Profitability memiliki nilai signifikansi sebesar 0,012 sehingga Ha peneliti diterima. Variabel Firm Size juga memiliki nilai signifikansi sebesar 0,001 sehingga $\mathrm{Ha}$ diterima. Variabel Liquidity didapatkan nilai signifikansi sebesar 0,000 sehingga Ha diterima. Variabel Business Risk memiliki nilai signifikansi 0,014 yang membuat Ha pun diterima, dan terakhir variabel Asset Structure mendapatkan nilai signifikansi sebesar 0,023 sehingga Ha peneliti diterima. Karena semua hasil uji t peneliti mendapatkan nilai signifikan dibawah 0,05 maka dapat disimpulkan semua variabel independen memiliki pengaruh yang signifikan terhadap variabel dependen yaitu variabel Capital Structure.

Berdasarkan hasil penelitian, maka didapatkan persamaan regresi linier berganda yaitu sebagai berikut:

$$
Y=-0,376-0,931 X_{1}+0,089 X_{2}-0,031 X_{3}-0,814 X_{4}-0,208 X_{5}
$$

\section{Kesimpulan}

Berdasarkan hasil uji statistik dan analisis penelitian yang telah dilakukan dapat disimpulkan sebagai berikut:

1. Variabel Profitability memiliki pengaruh yang signifikan terhadap Capital Structure perusahaan manufaktur sektor industri dasar dan kimia.

2. Variabel Firm Size memiliki pengaruh yang signifikan terhadap Capital Structure perusahaan manufaktur sektor industri dasar dan kimia.

3. Variabel Liquidity memiliki pengaruh yang signifikan terhadap Capital Structure perusahaan manufaktur sektor industri dasar dan kimia.

4. Variabel Business Risk memiliki pengaruh yang signifikan terhadap Capital Structure perusahaan manufaktur sektor industri dasar dan kimia.

5. Variabel Asset Structure memiliki pengaruh yang signifikan terhadap Capital Structure perusahaan manufaktur sektor industri dasar dan kimia.

\section{Daftar Pustaka}

Brealey A. Richard, Stewart C. Myers, Franklin Allen. (2011). Principles of Corporate Finance, Global Edition. New York: Me Graw Hill.

Brigham, Eugene F. dan Joel F. Houston. (2004). Fundamentals of Financial Management. Tenth Edition. Mason: Thomson South-Western.

Brigham, Eugene F. dan Michael C. Ehrhardt. (2008). Financial Management Theory And Practice. Twelfth Edition. Mason: Thomson South-Western. 
Firnanti, Friska. (2011). Faktor-Faktor Yang Mempengaruhi Struktur Modal Perusahaan Manufaktur di Bursa Efek Indonesia. Jurnal Bisnis dan Akuntansi. 13. (2). 119-128.

Furi, Vina Ratna dan Saifudin. (2012). Faktor - Faktor Yang Mempengaruhi Struktur Modal (Studi Empiris Pada Perusahaan Manufaktur Yang Terdaftar di BEI).

Ghozali, Imam. (2011). Aplikasi Analisis Multivariate Dengan Program SPSS. Edisi V. Semarang: Badan Penerbit Universitas Diponegoro.

Hardianti, Siti dan Gunawan, Barbara (2010). Pengaruh Size, Likuiditas, Profitabilitas, Risiko, dan Pertumbuhan Penjualan terhadap Struktur Modal (Studi Empiris pada Perusahaan Manufaktur di Bursa Efek Indonesia). Jurnal Akuntansi dan Investasi. Vol.11 No.2.Juli 2010.

Keown, A. J. dan J. D. Martin. (2010). Manajemen Keuangan: Prinsip dan Penerapan. Salemba Empat. Jakarta.

Riyanto, Bambang (2001). Dasar-Dasar Pembelanjaan Perusahaan. Edisi 4. Yogyakarta: BPFE Yogyakarta.

Ross, Stephen A., Randolph W. Westerfield, Bradford D. Jordan.(2009). Modern Financial Management. Singapore: McGraw Hill. 


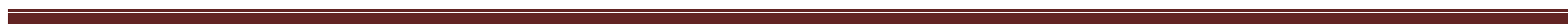
$\cdot$ 